\title{
Pattern of Indonesian Government's Political Will in Handling Covid-19 Pandemic
}

\author{
Fajar Rahmanto $^{1}$, Teuku Ade Surya ${ }^{2}$
}

\author{
${ }^{1}$ Department of Government Affairs and Public Administrations, Universitas Muhammadiyah Yogyakarta, Indonesia \\ ${ }^{2}$ Expertise Agency, Secretariat-General of Indonesian House of Representative, Jakarta, Indonesia \\ Corresponding author.Email: ${ }^{1}$ fajarrahmantol@gmail.com, ${ }^{2}$ soerya_roman@yahoo.com
}

\begin{abstract}
The widespread Covid-19 pandemic has become a severe threat to the global community. The accuracy of the political decisions made by the government in handling the outbreak is expected to be able to reduce the risks and harmful consequences caused. This article aims to determine the form of political will from the government in reducing potential risks due to the Covid-19 pandemic in Indonesia. The research method used is descriptive qualitative with a literature study approach. Secondary data collection techniques from previous references, books, internet, and documents related to the handling of Covid-19 in Indonesia were analyzed using NVivo12 Plus software with a Query analysis approach. The results of the study show that the Indonesian government's political will include setting policy priorities for handling the Covid-19 pandemic as an effort to protect the economic sector that endangers the national economy and maintain the state financial system, as well as protecting the public health sector through major social policies and public health emergencies. The key to the Government's political objectives in handling pandemic disasters is to suppress all potential threats from natural, economic, social, cultural, defense, and public security disasters.
\end{abstract}

Keywords: Political Will, Pandemic Management, Covid-19

\section{BACKGROUND}

Political will in the field of disaster management policy is driven by the existence of a state that has a full role in carrying out its duties to protect the population from all disasters that occur in the territory of Indonesia, as well as the application of risk disaster-based management program (Kartika, 2015). This requires coordination in improving the effectiveness of disaster management, which is influenced by different ways, work attitudes, tasks, commitments, procedures, financing, provision of supporting infrastructure and facilities, and capacity/competence (Ariyanto, 2018). For the formulation of public policy, it cannot be separated from the political process by the attitude of the actors involved in making policy decisions to produce political will in the form of goals to be achieved by the concerned elite (Siregar, 2018). Strategic preparation for disaster mapping, medical personnel placement, simple work distribution through disaster service innovation will benefit the wider community (Faradilla, 2018).

The spread of Corona Virus Disease 2019 (Covid-19) throughout the world occurs very quickly, with many confirmations related to the findings of people infected with this virus, where most occur in men aged 8-92 years and the risk of death reaches between $2 \%$ to $2.3 \%$ (Adnan Shereen et al., 2020; Arshad Ali., 2020; Lupia et al., 2020). The spread of the threat of Covid-19 is a clinical problem for the entire global population and also health resources due to the lack of reference knowledge about this new virus so that efforts to formulate antiviral and vaccination continue to be developed and evaluated on an ongoing base (Lai et al., 2020). Constraints in handling Covid-19 due to the lack of specific treatments coupled with uncertainty related to the way of transmission and the impact caused to the health of the wider community (Ling et al., 2020). In addition, it was mentioned the potential of 2019-nCoV which caused a pandemic to impact the soaring global economic tax burden of $\$ 30$ to $\$ 100$ billion so that the estimated burden of the world economy due to pressure from this virus was estimated to reach $1 \%-2 \%$ of GDP (Gross Domestic Product) which for currently more than $20 \%$ of world GDP is now contributed by China (Arshad Ali et al., 2020).

Coronavirus transmission has occurred since December 2019 through patterns of interactions that occur between humans with close contact (Jiang et al., 2020). In Indonesia, the virus began to cause panic in early March 2020, marked by an announcement from the government regarding 2 Indonesian citizens positively infected with the coronavirus or Covid-19. It continued to increase until mid-March 2020, the number of cases was 96 positive, infected with this virus with five victims declared dead (https://www.voice.com/yoursay/2020/03/16/092818/menyi kapi-virus-covid-19). Even though it has a sound pandemic preparedness system, it still needs to be supported by 
partnerships from each stakeholder and improve the quality of human resources (Simatupang, 2017). Strategic efforts that can be undertaken are to strengthen monitoring measures for individuals infected with Covid-19 to prevent the spread between individuals (Lai et al., 2020).

After becoming a global concern in early January 2020, the Covid-19 pandemic has become a new research review. Lai et al. (2020) show the findings that the SARS-CoV-2 disease outbreak and even the novel coronavirus (2019$\mathrm{nCoV}$ ) in China at the end of 2019 has become a serious global threat to the global public health. Research conducted by (Jiang et al., 2020) describes the findings that introduce remote Psychological Crisis Interventions (PCI) over the telephone or the Internet and treatment facilities that help resolve psychological problems created by this pandemic. A study conducted by (Djasr, 2020) shows that the existence of a Covid-19 pandemic must be used as a basis in good clinical governance studies with the preparation of health guidelines to be carried out consistently. Then a study from (Ling et al., 2020) states that to prevent the spread of Covid-19 from infected patients by maintaining hand hygiene, the availability of N-95 masks and personal protective equipment (APD) according to standards, a series of protocols and SOPs for prevention clear communication and cooperation between all stakeholders teams.

Seeing the many challenges and adverse effects caused by the outbreak of the Covid-19 pandemic throughout the world, including in Indonesia, and based on previous research on the Covid-19 pandemic, there has been no study or research that has tried to look at the handling of Covid from the government side as a policy maker. This is important because all the policies or programs for handling Covid-19 are a direct reflection of the government's political will when looking at issues, calculating risks, and even presenting solutions. Sources of study in this paper are from various literature reviews, previous works, notes, and even multiple articles relating to the handling of the Covid-19 pandemic.

\section{METHOD}

The research method in this paper uses a descriptive qualitative method with a literature study approach to obtain research data and information. The literature study approach is a way to obtain research information derived from books. The internet is closely related to the object of research (Farida, 2019). The collected information comes from a policy decision in handling Covid-19 by Indonesia Government in during march 2020 until 2021. In that month, Covid-19 began to cause many fatalities to become public attention. It can provide an overview of the shape of the political will taken by the government for handling Covid-19 in Indonesia. Then, to find out how strategic efforts through the political will of the government in handling Covid-19, the researcher uses analysis with the Query approach using the NVivo 12 Plus application. It is an application software developed for qualitative research that can effectively and efficiently conduct data analysis and display data displays in the form of tables, graphs, and diagrams (Bandur, 2019). As for the presentation of data in general in qualitative research conducted with matrices, graphs, charts, and narrative texts and concluding/verification which is the final stage of data analysis through the interpretation of research data.

\section{RESULT AND DISCUSSION}

\subsection{Government Political Will in Handling Covid- 19}

At the beginning of 2020, the world was shocked by the onset of the Covid-19 pandemic, whose spread has posed a risk to public health and has even claimed lives for people who have tested positive for this virus. Covid-19 is declared by the World Health Organization as a pandemic in most countries around the world, including Indonesia. It makes the public health authority continue to monitor the situation and conditions that occur as a preventive measure by continuing to learn about Covid-19 to build responses to this new virus and its related outbreaks (Lai et al., 2020). The lack of knowledge references to Covid-19 makes all countries increase high awareness to reduce the risk caused by this outbreak. The high knowledge gap regarding Covid-19 handling encouraged the entire world health community to jointly contribute to building and preparing a database related to Covid-19 from local, regional, to international levels (Ling et al., 2020). Proper preparedness in handling pandemic disasters must still be supported by collaborating with relevant stakeholders and improving the quality of human resources (Simatupang, 2017). Political will is also needed in disaster policies where the orientation of the state is to play a full role in carrying out the responsibility to protect the public from all threats posed by a disaster (Kartika, 2015). As for the distribution of Covid-19, the disaster management policies are determined as in the following table:

Table 1. Political will and goal of Indonesian highest authority

\begin{tabular}{|c|c|c|}
\hline Political Will & Goal-Oriented & Authority \\
\hline $\begin{array}{l}\text { government } \\
\text { regulations } \\
\text { Instead of Law } \\
\text { of the Republic } \\
\text { of Indonesia No } \\
1 \text { / } 2020\end{array}$ & $\begin{array}{l}\text { A state finance and financial } \\
\text { system stability policy for } \\
\text { handling Corona Virus } \\
\text { Disease } 2019 \text { (Covid-19). } \\
\text { To deal with threats that } \\
\text { endanger the national } \\
\text { economy and/or financial } \\
\text { system stability. }\end{array}$ & President \\
\hline $\begin{array}{l}\text { government } \\
\text { regulations } \\
\text { of the Republic } \\
\text { of Indonesia, No } \\
21 \text { / } 2020\end{array}$ & $\begin{array}{l}\text { Carrying out large-scale } \\
\text { social restrictions to } \\
\text { accelerate the handling of } \\
\text { Corona Virus Disease } 2019 \\
\text { (Covid-19) }\end{array}$ & President \\
\hline $\begin{array}{l}\text { Presidential } \\
\text { Decree of the } \\
\text { Republic of } \\
\text { Indonesia No } 11 \\
\text { / } 2020\end{array}$ & $\begin{array}{l}\text { Determination of public } \\
\text { health emergencies due to } \\
\text { Corona Virus Disease } 2019 \\
\text { (Covid-19) }\end{array}$ & President \\
\hline
\end{tabular}

Source: Data managed by author, 2020. 
Based on Table 1, it can be explained that in handling the Covid-19 pandemic in Indonesia, the role of the government that has all power with political will determined through various disaster management policies seeks to protect all Indonesian people from the threat of a Covid-19 pandemic as a national level disaster. The seriousness of the Indonesian government in setting the Covid-19 pandemic management policy has the main priority of protecting public health with various standard procedures for handling Covid-19 while maintaining national economic growth through the stability of the country's finances from the adverse effects of the Covid-19 pandemic. The widespread Covid-19 pandemic in Indonesia has become a serious threat if not handled properly. This requires political commitment from the government as the party that has the power to take strategic steps with a variety of policies that can prevent all the worst risks in all areas of life, including social, economic, and social welfare aspects. By mapping potential disasters, medical personnel allotment, clear division of work tasks and supported by HR competencies through good coordination and communication in carrying out disaster management, the effectiveness of disaster management benefits can be felt more by the wider community (Ariyanto, 2018; Faradilla, 2018).

The Covid-19 pandemic has also significantly disrupted economic activity and has significant implications for the economic impact of most countries in the world, including Indonesia. One of the potential disruptions to the national economy is the decline in Indonesia's economic growth which is predicted to be only around 4\% (four percent) or lower, depending on how long and how severe the spread of Covid19 affects community activities and economic activity. The disruption of economic activity will automatically have implications for the emergence of financial problems that can potentially change the 2020 State Budget in terms of State Revenues. The Covid-19 pandemic, which harms aspects of the country's economy because it threatens Indonesia's economic growth, requires policy responses to handling and extraordinary measures in the field of state finance, taxation, regional finance, and other financial sectors. All must be immediately decided through political will owned by the government and other related institutions to overcome the unstable economic conditions due to the Covid-19 pandemic. Thus, the accuracy of the political will decided by the government and strengthened with adequate regulatory instruments can provide a strong foundation for the state and related institutions to determine policies to prevent the outbreak of Covid-19 in Indonesia. Besides, the thing that is no less important in handling disasters is the need for increased coordination from all stakeholders in the field of disaster (Farizi et al., 2016).

The government needs to respond by taking strategic steps in the aspect of state finances as an effort to protect national health and economy directed at state spending on health, social safety net, and focus on economic recovery which includes the business world and affected communities with the purpose as an anticipatory measure (forward-looking) to maintain the stability of the country's financial sector.
Therefore, the government uses political will by taking steps to adjust the value of the budget deficit that exceeds $3 \%$ of the Gross Domestic Product (GDP) no later than until the end of the Fiscal Year 2022. Then after handling the Covid-19 pandemic to face potential threats to the national economy, the government gradually returns the amount of the budget deficit to a maximum position of $3 \%$ of Gross Domestic Product (GDP) for the Fiscal Year 2023. So, with its political will, the government in the economic sector establishes state financial policies and financial system stability for handling the Covid-19 pandemic in the face of threats that endanger the national economy and financial system stability. So as a strategic effort that can do is to increase aggressive steps to control people who are positive for Covid-19 to prevent the spread of this outbreak through direct contact between humans (Jiang et al., 2020; Lai et al., 2020).

Indonesia has established the Covid-19 pandemic as a non-natural disaster in the form of disease outbreaks that must be taken as a response to reduce the potential for more widespread so that there is no increase in the higher cases. Non-natural disasters have a risk impact with higher mortality than natural disasters (Masdalina Pane et al., 2018). Countermeasures made by the government to reduce the spread that is more widespread, namely the implementation of health quarantine. It becomes a joint responsibility authority between the government at the central and local levels as a form of protection to public health from the threat of disease or potential health risks that can cause emergencies in public health. Even though the health sector already has regulatory standards related to health services, community participation must strengthen disaster management (Hutagao, 2019).

The general level of Covid-19 distribution that transcends regions and countries impacts the political, economic, social, cultural, defense, and security aspects and the welfare of the people in Indonesia. Therefore, fast action is needed from the government in handling Covid-19 through the Large-Scale Social Restrictions policy as part of a strategic quarantine step to reduce the spread of Covid-19. The work was carried out with restrictions on certain activities of residents in an area suspected of being infected with Covid-19, including restrictions on the mobility of people or goods for one province, one particular district/city as part of efforts to prevent the spread of Covid-9). As for the forms of restrictions are carried out with policies to close schools and workplaces, restrictions on religious activities, and restrictions on activities in public areas or public facilities. In applying social restrictions (social distancing), the government must pay attention to the population's basic needs, including health service needs, food needs, and other daily life needs. To do disaster management, the primary requirement must be known to all stakeholders involved in disaster management (Moningka et al., 2018).

In handling Covid-19 disasters as one of the national hazards faced by the Indonesian government, it is necessary to pay attention to the steps that will be taken and have been 
done, including from patterns of communication between stakeholders in implementing Covid-19 disaster management policies. The communication aspect is one of the essential parts in implementing all activities, including handling a disaster so that disaster management can carry out properly, effectively, and efficiently. Through excellent communication and coordination, patterns can build community trust and maintain the stability of public psychology so as not to be overwhelmed by panic, excessive anxiety and fear due to the risk of a Covid-19 pandemic so that the handling of this epidemic disaster runs smoothly for disaster management policies to run optimally (Silmi et al., 2019), which will provide easy access to information for the community and all parties related to Covid-19 handling.

Political Will from a President as the head of government through direct instruction or carried out with policies handling Covid-19 to show the public that the country is highly committed, the country is ready and able to handle the occurrence of a Covid-19 pandemic that Indonesian hits. Therefore, the perception of the government's readiness and seriousness needs to be conveyed to the public through a comprehensive and periodic explanation by explaining what the government has and will do. Cross-sectoral support both between government agencies at the central level and the Local Government level to carry out communication and coordination needs to increase in the face of the threat of the Covid-19 outbreak. Effective disaster management can be achieved by increasing coordination and communication (Ariyanto, 2018). Thus, in dealing with all the potential risks of Covid-19, people remain calm by understanding what they must do for their immediate environment. The urgency of the community to understand how disaster management is crucial in efforts to build community preparedness to face the Covid19 pandemic. Knowledge of disasters in the form of information and the first action when a disaster occurs can use as relevant information material that can be immediately published to the public at large (Juneza \& Puworini, 2016).

Political Will as a tool to develop the government's narrative during a crisis due to Covid-19 through disaster management policies has been determined to control the unstable public situation due to the Covid-19 disaster. In the disaster management stage, the government created the narration as part of building a positive image of the public that the country is ready and able to handle the crisis. The main narrative in the delivery of communication by the Central Government and Regional Governments to the public was the hashtag (\#LAWANCOVID19). In fact, this hashtag is a form of communication between the government and the community which will be analyzed further.

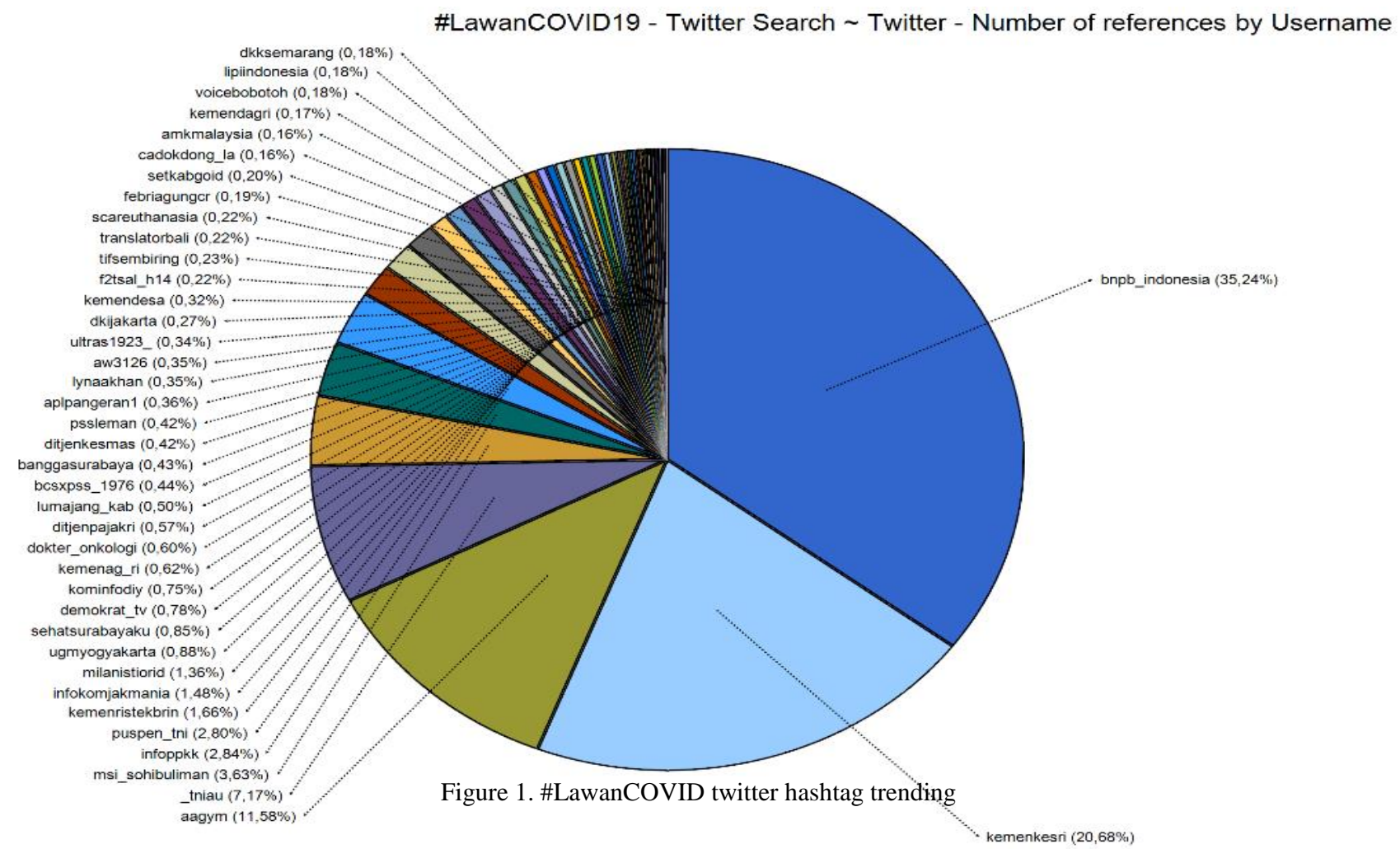

One of the social media that is currently widely used to disseminate information related to disaster data is Twitter. In the field of disasters, the use of Twitter as a medium for disseminating information about disasters has proven to be effective. It shows from previous research conducted by (Nee
\& Fusco, 2015). That the spread of information in tweets stating about disasters is more posted than broadcasting disaster news in journalistic media. Like when the coronavirus disaster (Covid-19) has become a global issue and has become a significant trend in various countries 
because it has proven to hurt all sectors of life, ranging from health threats to chaos in the economic area. Covid-19, which spreads very quickly throughout the world (Lupia et al., 2020), including in Indonesia, has encouraged Twitter users both from the public and government organizations to respond rapidly to the pandemic outbreak through various posts, tweets, and hashtags (\#hashtag) about Covid-19. Its means that here is the use of social media Twitter as a motivating part of the social movement of the community in its participation and response to efforts to overcome disasters based on social motives (Mahaswari, 2012). The intended social motivation associated with the Covid-19 pandemic is to build a public perception that the state is present and responsive in controlling the crisis due to the spread of the Covid-19 pandemic in the Indonesian territory.

To accelerate the mobilization of information and communication on disaster management, Covid-19 can be done by utilizing the power of social media. Social media becomes an effective means of promotion or socialization related to disaster information with all its advantages. Anyone can access it to afford the affordability of information to the broader community (Handayani et al., 2018). It is inseparable from the characteristics of social media itself, which can penetrate time, affordability, and content and be more flexible (can be anytime and anywhere). The role of social media can create new patterns in communication and social participation between government organizations, the private sector, and society that have utilized as information media that are easily accessible to the public (Subekti et al., 2020).

\subsection{Impact of the Covid-19 Pandemic}

The Covid-19 outbreak that originated in China has rapidly spread to other countries (Arshad Ali et al., 2020). The World Health Organization (WHO) itself states that there are more than 100,000 cases internationally, resulting in the deaths of more than 3,000 people. Its rapid distribution has made several regions in Indonesia vulnerable, namely Jakarta, Surakarta, Depok, Bogor, Tangerang, Bekasi, and several other areas in Central and East Java. Handling from the regional government was diverse, ranging from laying off community activities, including schooling, to the enactment of outbreaks (extraordinary events) such as in the Surakarta region. The outbreak of the virus eventually resulted in sluggish economic growth in several countries, including Indonesia, the prohibition of foreign visits.

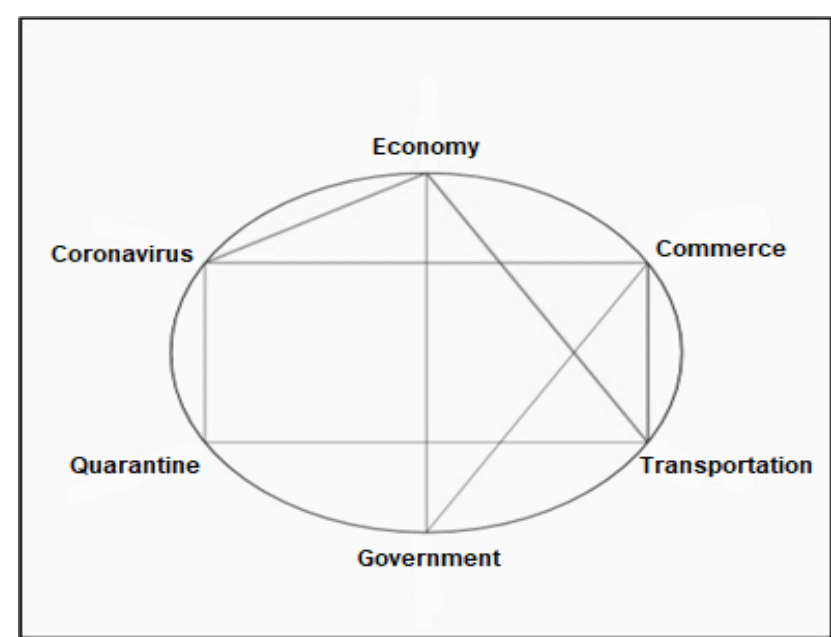

Figure 2. impact caused by the Covid-19 pandemic

Figure 2 can explain the impact caused by the Covid-19 pandemic for Indonesia, which significantly influences the economy and trade sectors. Coronavirus has made the wheels of the economy of various countries, including Indonesia, experience massive paralysis. The rapid spread of Covid-19 made the government take anticipatory steps by limiting human mobility and the flow of goods/services. The impact of reducing public transportation and the transportation of goods disrupted the smooth flow of distribution in trade activities. As a result, the economy has almost stopped because domestic consumption has supported nearly $60 \%$ of Indonesia's Gross Domestic Product (Abdini, 2020). By considering the high risks caused by the occurrence of a disaster, each region must try to mitigate as a step to reduce the adverse effects of the disaster that occurred (Tamitiadini et al., 2019).

Through various appeals from the government and policymaking, quarantine is carried out to reduce outdoor activities and stay at home as a form of quarantine that is independent to prevent the widespread impact of the spread of Covid-19 in Indonesia. It has the consequence of disruption to the operational activities of companies and the real sector, tiny and medium enterprises (MSMEs), losing their customers, resulting in a decrease in the number of profits obtained. Besides this, Covid-19 also gave rise to negative sentiment to the market and investors. The impact is on the rupiah's exchange rate against the dollar is increasingly pressing up to Rp16,200 or almost close to the lowest point of the rupiah at Rp16,950 when the 1998 monetary crisis occurred. (Abdini, 2020).

\subsection{Efforts to Prevent Potential Risks of the Indonesian Government's Covid-19 Pandemic}

The increasing spread of Covid-19 has posed threats to social, economic, and social welfare. The Covid-19 pandemic outbreak caused slowing national economic growth, decreased state revenue, and caused an increase in state spending and financing. As a result, it impacts the decline in various domestic economic activities. The state's role through 
a political will as a policymaker in dealing with crises due to the Covid-19 pandemic must do carefully and precisely to be able to create a civil society and understand what they must do for the surrounding environment. So, in this case, a clear understanding of the direction of the policy is needed to prevent the potential risk of the spread of the Covid-19 pandemic by all parties, including the community (Ariyanto, 2018; Kartika, 2015). Building public perceptions that the state is present and responsive in controlling crises can do through efforts to prevent the potential risk of a Covid-19 pandemic in the public area, as illustrated below.

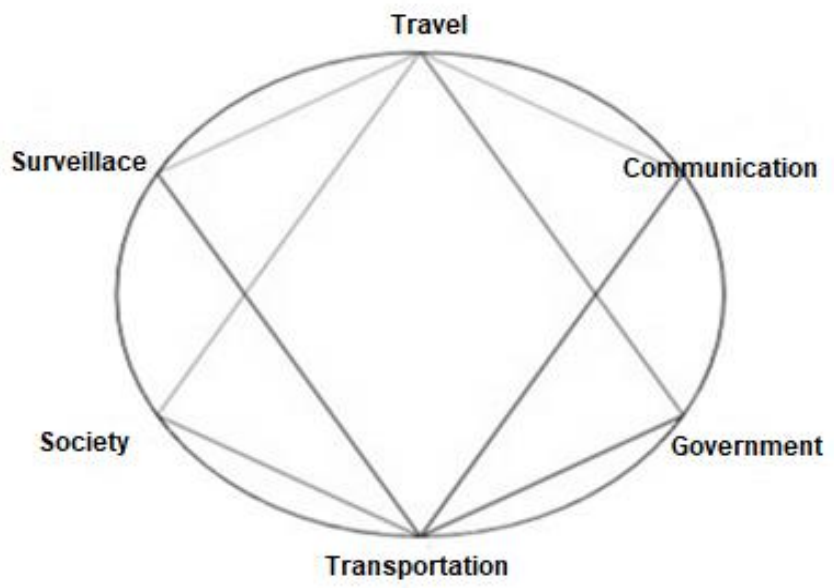

Figure 3. Government's efforts to prevent the Covid-19 spread

Figure 3 shows the government's efforts to prevent the spread of the Covid-19 pandemic in the public area carried out with supervision of every trip carried out by the public through public transportation both land, sea, and air transportation. The form of government supervision to anticipate the spread of this pandemic is to require all public place managers and public transportation to always clean using disinfectants at least three times a day during peak hours of activity in the morning, afternoon, and evening at each representative location such as door handles, buttons elevator, escalator handle and others. Also, screening of body temperature is regularly checked. Furthermore, public communication as a form of education to the community by promoting and socializing the ethics of coughing/sneezing in public places and public transportation is always conducted. Moreover, the government always urges the public to carry out social and physical distancing by not carrying out mass collection activities in large quantities to prevent direct physical contact. The spread of Covid-19 between people is faster so that a clear set of protocols and SOPs is needed as well as communication and cooperation of all stakeholders, both active community participation and fierce commitment from government agencies in implementing policies to prevent the spread of Covid-19 (Adnan Shereen et al., 2020; Ling et al., 2020).

\section{CONCLUSION}

The government's political will, as a form of strong commitment in handling pandemic disasters, aims to reduce all potential risks of disasters that endanger the country from political, economic, social, cultural, defense, and security aspects, as well as people's welfare. The political will of the government to set priorities for strategic measures for handling the Covid-19 pandemic disaster is done as an effort to protect the economic sector and public health through social restriction policies large-scale (social distancing). Public health emergencies as an anticipatory measure were able to suppress the spread of a pandemic that can cause an increase in the number of cases and fatalities.

\section{REFERENCES}

Abdini, C. (2020). How the Government Should Act in the Worst Scenario of the COVID-19 Outbreak Retrieved March 24, 2020, from https://theconversation.com/howthe-government-harus-bertindak-dalam-skenarioterpasar-wabah-\%0Acovid-19-134246

Adnan Shereen, M., Khan, S., Kazmi, A., Bashir, N., \& Siddique, R. (2020). COVID-19 Infection: Origin, Transmission, and Characteristics of Human Coronaviruses. Journal of Advanced Research. https://doi.org/https://doi.org/10.1016/j.jare.2020.03.00 5

Ariyanto, D. (2018). Institutional Coordination in Improving the Effectiveness of Regional Disaster Management Agency. Journal of Management Review, 2(1), 161172.

Arshad Ali, S., Baloch, M., Ahmed, N., Arshad Ali, A., \& Iqbal, A. (2020). The Outbreak of Coronavirus Disease 2019 (COVID-19)-An Emerging Global Health Threat. Journal of Infection and Public Health, xxx, 1-3. https://doi.org/https://doi.org/10.1016/j.jiph.2020.02.03 3

Bandur, A. (2019). Qualitative Research, Scientific MultiDisciplinary Study with NVivo 12 Plus (First Edition). Jakarta: Media Discourse Partners.

Barata, GK, Lestari, P., \& Hendariningrum, R. (2018). Communication Model for Mount Merapi Disaster Management Through Plewengan Application. Journal of Communication Spectrum, 7(2), 31-45.

Djasr, H. (2020). Corona Virus and Quality Management of Clinical Services in Hospitals. Journal of Hospital Accreditation, 02(01), 1-2.

Faradilla, M. (2018). Role of Pharmacist in Disaster Management. Pharmaceutical Sciences and Research, 5(1), 14-18.

Farida, A. (2019). Literature Study on Technological Developments and Improving Tax Compliance: Is it Directly Comparable? Monetary - Journal of Accounting and Finance, 6(2), 135-140. https://doi.org/10.31294/moneter.v6i2.6183 
Farizi, I., Ismail, N., \& Aulia, TB (2016). Preparedness Analysis Uptd Health Crisis Management Center (P2kk) Aceh Health Office in Facing Earthquake Disasters. Journal of Disaster Science (IF), 3(2), 85-93.

Handayani, VW, Soelistiono, S., \& Sylvaranto, T. (2018). The Effect of the Volcano Disaster Module on Improving Preparedness for Volcanic Disasters Through Facebook Case Study: Elementary School Teacher using FB in Sumber Wringin District, Bondowoso Regency. Scientific Journal of Business Administration and Innovation, 2(2), 236-263.

Hutagao, EK (2019). Health Problems in Disaster Conditions: Role Of Community Participation Health Officers. Medical Scientific Journal of the Institute of Medicine, $1(1)$.

Jiang, X., Deng, L., Zhu, Y., Ji, H., Tao, L., Liu, L., ... Ji, W. (2020). Psychological crisis intervention during the outbreak period of new coronavirus pneumonia from experience in Shanghai. Psychiatry Research, 286, 112903. https://doi.org/10.1016/j.psychres.2020.112903

Juneza, RRD, \& Puworini, D. (2016). Responses of Persons with Disabilities to Crisis Communication BPBD (Regional Disaster Management Agency) and Klaten SAR Team 2016. 10(1), 80-96.

Kartika, SD (2015). Legal Politics of Natural Disaster Handling. Journal of Studies, 20(4), 329-342.

Lai, CC, Shih, TP, Ko, WC, Tang, HJ, \& Hsueh, PR (2020). Severe acute respiratory syndrome coronavirus 2 (SARS-CoV-2) and coronavirus disease-2019 (COVID19): The epidemic and the challenges. International Journal of Antimicrobial Agents, 55(3), 1-8. https://doi.org/10.1016/j.ijantimicag.2020.105924

Ling, L., Joynt, GM, Lipman, J., Constantin, JM, \& JoannesBoyau, O. (2020). COVID-19: A Critical Care Perspective Informed by Lessons Learned from Other Viral Epidemics. Anaesthesia Critical Care and Pain Medicine, $\quad \mathrm{xxx} \quad$ (4), 2-5. https://doi.org/10.1016/j.accpm.2020.02.002

Lupia, T., Scabini, S., Pinna, SM, Di Perri, G., De Rosa, FG, \& Corcione, S. (2020). 2019-Novel Coronavirus Outbreak: A New Challenge. Journal of Global Antimicrobial Resistance, 21, 22-27. https://doi.org/10.1016/j.jgar.2020.02.021

Mahaswari, M. (2012). Jalin Merapi: Use of New Media and Social Movements for Disaster Management. Indonesian Journal of Communication, I (2), 68-76.

Masdalina Pane, Isturini, IA, \& Wahidin, M. (2018). Management of Health Crisis in Indonesia, 2016. Media Litbangkes, 28(3), 147-156. https://doi.org/https://doi.org/10.22435/mpk.v28i3.115

Moningka, RR, Setyohadi, DB, Khaerunnisa, \& Pranowo. (2018). Identification of Basic Needs in Temporary Evacuation Sites Post-Eruption of Merapi with Sentiment Analysis and Support Vector Machine. Telematics, 15(01), 77-86.
Nee, RC, \& Fusco, J. (2015). Tweets During Crisis Follow One-Way Communication. Newspaper Research Journal, 36(2), 197-211. https://doi.org/http://doi.org/10.1177/07395329155872 95

Silmi, NR, Nur, T., \& Purwanti, D. (2019). Implementation of Regional Disaster Management Policy in Sukabumi City. Joppas: Journal of Public Policy and Administration Silampar, 1(1), 30-40.

Simatupang, RB (2017). Hospital Disaster Preparedness of Indonesian Army Central Hospital Gatot Soebroto For Pandemics To Anticipate Bioterrorism Threat. Journal of Disaster Management Study Program, 3 (2), 49-80.

Siregar, H. (2018). Political Policy Studies: Actors and Issues in the Decision-Making Process. Journal Communitarian (Political Science Study Program), 1(1), 87-100.

Subekti, P., Hafiar, H., \& Bakti, I. (2020). The use of Instagram by the Regional Disaster Management Agency to optimize Pangandaran's destination branding. Journal of the Public Relations Profession, 4(2), 174192. Retrieved from http://jurnal.unpad.ac.id/profesihumas

Tamitiadini, D., Dewi, WWA, \& Adila, I. (2019). NonStructural Disaster Mitigation Model Innovation Based on Communication, Information, Coordination and Cooperation. Proceedings of Comnews 2019, 204-214.

Yulfa, A., Aditya, T., \& Sutanta, H. (2019). Spatial Data Infrastructure Enrichment using Crowdsourced Data for Emergency Response. Globe Scientific Magazine, 21(2), 95-104. Retrieved from http://dx.doi.org/1024895/MIG.2019.21-2.936 